Article

\title{
Governance through Economic Paradigms: Addressing Climate Change by Accounting for Health
}

\author{
Kristine Belesova ${ }^{1}$, Ilan Kelman ${ }^{2,3, *}$ and Roger Boyd ${ }^{4}$ \\ ${ }^{1}$ Social and Environmental Health Research Department, London School of Hygiene and Tropical Medicine, London, \\ WC1H 9SH, UK; E-Mail: kristine.belesova@Ishtm.ac.uk \\ ${ }^{2}$ Institute for Risk \& Disaster Reduction and Institute for Global Health, University College London, London, WC1E 6BT, UK; \\ E-Mail: ilan_kelman@hotmail.com \\ ${ }^{3}$ University of Agder, Kristiansand, Norway \\ ${ }^{4}$ Independent Researcher, Canada; E-Mail: rogerboyd99@gmail.com \\ * Corresponding author
}

Submitted: 28 August 2016 | Accepted: 19 October 2016 | Published: 28 December 2016

\begin{abstract}
Climate change is a major challenge for sustainable development, impacting human health, wellbeing, security, and livelihoods. While the post-2015 development agenda sets out action on climate change as one of the Sustainable Development Goals, there is little provision on how this can be achieved in tandem with the desired economic progress and the required improvements in health and wellbeing. This paper examines synergies and tensions between the goals addressing climate change and economic progress. We identify reductionist approaches in economics, such as 'externalities', reliance on the metric of the Gross Domestic Product, positive discount rates, and short-term profit targets as some of the key sources of tensions between these goals. Such reductionist approaches could be addressed by intersectoral governance mechanisms. Health in All Policies, health-sensitive macro-economic progress indicators, and accounting for long-term and nonmonetary values are some of the approaches that could be adapted and used in governance for the SDGs. Policy framing of climate change and similar issues should facilitate development of intersectoral governance approaches.
\end{abstract}

\section{Keywords}

climate change; disaster risk reduction; economic growth; health; health in all policies; sustainable development; sustainable development goals

\section{Issue}

This article is part of the issue "Disaster Policies and Governance: Promoting Community Resilience", edited by Naim Kapucu (University of Central Florida, USA) and Abdul-Akeem Sadiq (Indiana University-Purdue University Indianapolis, USA).

(C) 2016 by the authors; licensee Cogitatio (Lisbon, Portugal). This article is licensed under a Creative Commons Attribution 4.0 International License (CC BY).

\section{Introduction}

Governance for the Millennium Development Goals (MDGs; United Nations [UN], 2015) from 2000-2015 was critiqued for not having fully considered interactions among the goals (Waage et al., 2010). When the Sustainable Development Goals (SDGs; UN Sustainable Development Platform, 2015) were developed for 2015-2030 to succeed the MDGs, efforts were made to emphasize potential interactions among them (Waage et al., 2015). The 17 SDGs are supported by 169 targets with numer- ous indicators specified at global, regional, and national levels. Such a framework offers an opportunity to identify and exploit beneficial interactions among the goals. In order to design such governance mechanisms and to ensure their effectiveness, it is essential to examine possible tensions and synergies among the SDGs, thereby learning and applying the lessons from what was rarely achieved for the MDGs.

We examine links between SDG 13 addressing climate change and SDG 8 on economic growth, focusing on accounting for their links with SDG 3 on human health 
and wellbeing to illustrate how intersectoral governance approaches could benefit governance for the SDGs. This approach is comparatively unique because the interactions among such ostensibly disparate SDGs have rarely been investigated in detail. Most comparative analyses of SDGs thus far (e.g. Waage et al., 2015) adopt a broadbrush picture for governance framing, rather than detailed critiques of connections among selected goals.

Climate change has been proposed as a major challenge for sustainable development (Intergovernmental Panel on Climate Change [IPCC], 2014; UN, 2015; Worldwatch Institute, 2015). SDG 13 is devoted to climate change: "Take urgent action to combat climate change and its impacts" (UN Sustainable Development Platform, 2015). The specific targets of this goal cover both climate change mitigation (reducing greenhouse gases and increasing their sinks) and climate change adaptation (adjusting to climate change impacts), for this paper collectively termed "climate change action".

The achievement of SDG 13 is challenged by continued pursuit of unsustainable economic progress. SDG 8 sets a target for further economic growth for some countries: "Sustain per capita economic growth in accordance with national circumstances and, in particular, at least $7 \%$ gross domestic product growth per annum in the least developed countries" (UN Sustainable Development Platform, 2015). Another target of SDG 8 is set for decoupling economic growth from environmental degradation, as per the 10-year framework of programmes on sustainable consumption and production (UN Sustainable Development Platform, 2015).

So far, there has been no absolute decoupling of economic growth from greenhouse gas emissions (Steinberger, Krausmann, Getzner, Schandl, \& West, 2013). This may present a significant challenge to the simultaneous achievement of both effective climate change action and economic growth. Furthermore, some argue that climate change may cause significant harm to the global economy, mainly by disrupting set processes and interfering with established mechanisms for creating economic wealth, as measured by Gross Domestic Product (GDP) (Cole, 2007; Weitzman, 2007).

Population health is rarely explicitly considered in decisions pertaining to economic growth even though it is an implicit part of such determinants of growth as labour productivity and human resources. Similarly, the 10-year framework of programmes on sustainable consumption and production, which is the policy and governance mechanism for decoupling economic growth from environmental degradation, suggested in the SDGs, does not refer to human health (UN, 2012).

Both climate change impacts and unsustainable economic growth are expected to have overall negative impacts on the health of populations, although it is always a balance with some positive impacts seen, often delineated by location and subpopulation. To avoid contradictions among the SDGs, such as on climate change and economic growth, their impacts on health targets spec- ified in SDG 3 could be helpful for determining suitable intersectoral governance approaches.

In this paper, we first explain the key tensions between the goals for economic growth and climate change action. We then provide insight into paradigmatic sources of these tensions. Finally, we illustrate how the link of economic growth with climate change is likely to be mediated through human health and then we discuss ways of recognizing how this and similar links could benefit the design of more sustainable intersectoral governance approaches.

\section{Economic Growth as a Driver of Climate Change}

Major tension between SDGs 8 and 13 lies in the continued contribution of key drivers of economic growth in the furthering of climate change.

Economic growth has been closely linked to high levels of fossil fuel use and greenhouse gas emissions, which perpetuate anthropogenic climate change. In 20132014, 306 tonnes of carbon dioxide were produced per each USD 1 million of the global GDP (PWC, 2015). Such a rate of greenhouse gas emissions requires a $6.3 \%$ rate of reduction in the carbon intensity of global economic growth to achieve the climate change target of atmospheric warming down to $2{ }^{\circ} \mathrm{C}$ above the pre-industrial average which was set in the Paris Agreement from December 2015 (United Nations Framework Convention on Climate Change [UNFCCC], 2015).

The current global economic system was developed during a period of carbon-intensive rapid economic growth (Hall \& Klitgaard, 2011; Henriques, 2011; Kraussman \& Haberi, 2002), which in many ways it was designed to facilitate (Demirguc-Kunt \& Levine, 2001; Fitzgerald, 2006; Rousseau \& Sylla, 2001). This has left the global economy heavily dependent upon the continuation of such growth. Canadell et al. (2007) describe how, from 2000-2006, the carbon emissions required to produce a dollar of global economic activity unit have increased approximately $0.3 \%$ per year with Peters et al. (2012) reporting a $0.9 \%$ increase for 2010 which they attribute principally to burning fossil fuels and producing cement.

According to the Environmental Kuznets Curve hypothesis, economic growth first creates environmental problems, but later serves to reduce them (Grossman \& Krueger, 1995). With respect to climate change, the result should be an absolute decoupling of growth from greenhouse gas emissions; i.e., GDP can increase without increasing greenhouse gas emissions (Schandl et al., 2015). Although some relative decoupling of economic growth from greenhouse gas emissions has been achieved through enhanced energy efficiency and an increasingly service-based economy, there has not yet been absolute decoupling (Steinberger et al., 2013).

The small relative decoupling of $1.3 \%$ annual decrease in the carbon intensity of global economic growth (PWC, 2015) has been more than offset by the high rate of carbon-intensive economic growth. Between 2004 
and 2014, global GDP growth of $44 \%$ produced an increase in greenhouse gas emissions of 22\% (Handrich, Kemfert, Mattes, Pavel, \& Thure, 2015). Hence, the pursuit of economic growth, as it is currently generated, does not meet the environmental sustainability criteria in relation to climate change mitigation.

Target 4 of SDG 8 suggests decoupling economic growth from environmental degradation following a framework of programmes on sustainable consumption and production (UN, 2012). Documentation of this framework uses the word "sustainable" without defining or providing criteria of "sustainable". Hence, interpretation of target 8.4 hinges on the definition of "sustainable" and "sustainable economic growth". It might potentially refer to "sustained"; i.e., forever and hence assuming infinite availability and use of carbon-intensive resources for economic growth.

\section{Economic Growth and Climate Change Driving Different Priorities}

Another level of complexity augmenting the tension between SDGs 8 and 13 is different levels of vulnerability to climate change impacts of those with different power in making decisions pertaining to economic growth and who may interpret "sustainable economic growth" differently.

Sectors that would benefit most from rapid economic growth tend to have high capacity to protect themselves from the impacts of climate change on their health and wellbeing. For example, Canary Wharf, one of London's financial centres, is located in a zone highly vulnerable to storm surge flooding (Dawson, Hall, Bates, \& Nichloss, 2005; Jacob, Gornitz, \& Rosenzweig, 2007). Although the Thames Barrier provides some protection, to a large extent its construction facilitated the development of this financial centre due to the perception of it being safe from floods (Ward \& Smith, 1998). Under climate change, without changes to the Thames Barrier, the Barrier may be inadequate to prevent a major disaster costing hundreds of billions of pounds (Dawson et al., 2005). Thames Barrier upgrades are being discussed now, for plans covering the rest of the century (Environment Agency London, 2012). Hence, despite the climate-related risks, the financial sector has resources to offset their potential losses through constructing ostensibly protective physical infrastructure, using protective financial services (e.g., insurance), and diversifying assets. To maintain resources of the financial sector for such protection, the preferred interpretation of the term "sustainable economic growth" in the SDG 8 may indeed be "sustained".

By contrast, those who have contributed least to greenhouse gas emissions are those who are starting now to experience adverse impacts from climate change and who are likely to advocate for carbon-neutral or carbon-negative "sustainable economic growth" (Brulle, 2015; Parks \& Roberts, 2010). Locations highlighted are indigenous peoples in the Arctic and those living along coasts, such as in Bangladesh, Kiribati, Maldives, and Tuvalu (IPCC, 2014). In risk analysis language, the risk takers are different from the risk makers (Glantz, 1996; Glantz \& Jamieson, 2000). Several low-lying island countries organised a 1989 conference highlighting their vulnerability to sea-level rise impacts (Island Vulnerability, 1989), which garnered little action outside of the island states. A generation later, some of the island communities are being forced to deal with climate change related challenges physically (Storlazzi, Elias, \& Berkowitz, 2015) and socially (Kelman, 2015)-which is also occurring in some Alaskan communities (Bronen \& Chapin III, 2013).

The closed élite circle of financial decision-makers and the technical complexity of the economic decisionmaking tools, alongside weak accountability of the decision-makers, further complicates transparency in, and possible involvement from, sectors with differing priorities regarding "sustainable economic growth".

\section{Sources of Tension: Reductionist Paradigm in Economics}

The underlying sources of the above-discussed tensions to a large extent lie in reductionist paradigms of economics. The dominant theory and practice of economics today, including methods for estimating economic growth, do not sufficiently account for the complex interactions of economic activities with outcomes such as climate change and its impacts. The concept of "externalities", reliance on the GDP metric, positive discount rates, and short-term profit targets illustrate how these important links are omitted from economic considerations.

Impacts of greenhouse gas emissions on the atmosphere, and consequently on human health, tend to be treated as "externalities" (Brandt et al., 2010; Matthews \& Lave, 2000; Navrud, 2001). The term "externalities" describes the effects of production or consumption of goods and services, whose costs and benefits are not reflected in prices of goods and services provided (OECD, 2003). Hence, greenhouse gas emissions and their impacts tend to be external to cost-benefit calculations over the short-term.

Social and health effects of activities that contribute to economic growth, measured by GDP, are similarly often treated as "externalities". In GDP calculations, war expenditures are judged the same as costs to feed and educate the population. Moreover, after a given level of GDP per capita, additional economic growth tends not to produce increases in wellbeing (Anielski, 2007) or happiness (Inglehart, Foa, Peterson, \& Welzel, 2008; Layard, 2003, 2005; Stott, 2012). Hence, GDP can be better characterized as a measure of market-based expenditures, which does not judge whether a given expenditure increases or decreases social welfare.

Another example is the use of positive discount rates. A discount rate is used to calculate how much avoided 
future damage, e.g., from a flood, would be worth compared to the initial cost of actions needed to avoid the damage. In relation to climate change, the effects of which manifest over the long-term, positive discount rates value future impacts at a fraction of current costs (Beckerman \& Hepburn, 2007; DeCanio, de Lavergne, \& Palter, 2003). The use of positive discount rates is wellcritiqued in the literature for valuing the present more than the future (Beckerman \& Hepburn, 2007; DeCanio et al., 2003). Given positive discount rates, few economic incentives exist to avoid climate change, due to its longterm effects.

Furthermore, short-term profit targets are motivated by shareholder and investor pursuit of immediately optimal financial performance and successful revenue management by businesses, foregoing long-term and nonmonetary value creation (EY Poland, 2014). Most business models do not take into account long-term benefits or consequences of their activities, including climate change, or non-monetary values benefitting human health and wellbeing (Paulson, 2015).

Such reductionist thinking renders some economic, financial, and business models to portray climate change action as a costly and irrational act for stakeholders involved in the production of economic growth at all levels: governments, corporations, investors, producers, and consumers.

\section{Sources for Synergies: Climate Change Impacts on Economic Growth via Health}

The reductionist paradigm is not consistent with the current scientific understanding of the links between climate change and economic growth. Considering health impacts of climate change and their further implications for economic growth highlights potential shortcomings of working towards the SDGs without addressing the aforementioned reductionist approaches.

Indirect climate change impacts on health are rarely accounted for in estimates of the economic impacts of climate change. However, recent scientific evidence suggests that these impacts have significant implications for labour productivity and human resources. Higher temperatures are shown to be associated with a decrease in the productivity of those performing heavy labour outdoors and, when air conditioning is not available, indoors (Sahu, Sett, \& Kjellstrom, 2013). Furthermore, higher temperatures would lead to fewer hours of physiologically safe temperatures for work in non-air conditioned spaces. In South-East Asia, 15-20\% of annual work hours are estimated to be already lost under the current climatic conditions; this loss could double by 2050 under projected climatic change (Kjellstrom, 2015).

The projected climate change related decreases in global food availability would challenge the decline of global child undernutrition rates achieved over past decades (UN, 2015). This may subsequently lead to a rise in the long-term consequences of childhood un- dernutrition, such as lower performance of the immune system (Dercon \& Porter, 2014), increased risk of chronic diseases (Black et al., 2013), compromised cognitive development (Ampaabeng \& Tan, 2013), and lower economic productivity in adulthood (Dewey \& Begum, 2011), all further challenging labour productivity and human resources.

As such effects compound, in addition to the health and welfare of people, production and consequently economic growth could be increasingly afflicted. Labour productivity loss is the most substantial economic loss that the world would face from climate change (DARA \& Climate Vulnerable Forum, 2012). Already in 2010, the loss of labour productivity globally was suggested as being equated to the net loss of USD 311 billion (2010 PPP), which is around $0.5 \%$ of the global GDP (DARA \& Climate Vulnerable Forum, 2012). By 2030, the net loss due to compromised labour productivity is projected to reach USD 2.4 trillion per annum (DARA \& Climate Vulnerable Forum, 2012). Knock-on effects from these labour impacts mean that even atmospheric warming by $2{ }^{\circ} \mathrm{C}$ above the pre-industrial levels is projected to result in a loss of USD 4.2 trillion in the asset management industry from the private sector perspective, which is equivalent to the world's listed value of all oil and gas companies combined and which is the equivalent of Japan's GDP (The Economist Intelligence Unit, 2015).

The link illustrated here emphasizes that population health, which is essential for economic growth, will be (and in some places already is) constrained by climate change. The previously discussed reductionist approaches in economics would leave this link unaddressed. By contrast, integrated intersectoral governance approaches designed on the basis of understanding interactions across the SDGs could provide political space for addressing the complex indirect impacts and could further incentivize synergistic action on climate change across sectors.

\section{Suggestions for Intersectoral Governance Approaches: Beyond Reductionism}

Links across the SDGs, such as the indirect impact of climate change on economic growth through its impact on health, emphasize the need to govern SDGs in an integrated manner. We discussed four economic paradigms not conducive to such integrated governance approaches, especially as they impede climate change action: (1) the construct of "externalities", (2) reliance on the metric of GDP, (3) discount rates, and (4) shorttermism. Alternative governance processes can be suggested for each of these paradigms. We provide three examples of existing governance mechanisms that could be used to counter these paradigms by considering the links of SDG 3 with SDGs 8 and 13. We conclude this section with a case study on the framing of climate change and disaster risk reduction in wider policy contexts, illustrating the need for policies to be formulated 
in a way that facilitates development of such integrated governance mechanisms.

\subsection{Health in All Policies: To Value "Externalities" and Short-Term Health Co-Benefits}

Health in All Policies (HiAP) promoted by the World Health Organisation is "an approach to public policies across sectors that systematically takes into account the health implications of decisions, seeks synergies, and avoids harmful health impacts in order to improve population health and health equity" (World Health Organization, 2014). It draws attention to the consequences of public policies on the determinants of health, aiming to improve policy makers' accountability for health impacts of their decisions (World Health Organization, 2014).

In governance for SDGs, HiAP could be used to incorporate health implications across time scales into costbenefit considerations made by stakeholders from international to individual levels and across sectors. Tools such as the Health Impact Assessment and Health Risk Assessments could be adapted to suit the range of possible interactions across the SDGs and incorporated as a regulatory element of governance for the SDGs (Winkler et al., 2013). These elements could help to counter the paradigm of health implications being treated as "externalities" in day-to-day economic decisions as well as to link health with promoting the "green economy" (Winkler et al., 2013).

HiAP could also be used to develop intersectoral policy structures and to provide space for representatives of the health sector to communicate health implications to decision-makers in other sectors. For example, in a debate on discount rates, health sector representatives could lobby for climate change action in spite of positive discounting by emphasizing the immediate health benefits of many choices in favour of climate change mitigation, such as the positive health consequences of reduced car use, including cleaner air and reduced cardiovascular disease (Watts et al., 2015).

\subsection{Health-Sensitive Macro-Economic Progress Indicators}

The UN Statistical Commission and the Inter-Agency and Expert Group on Sustainable Development Goal Indicators have been coordinating the development of an overarching framework of indicators for monitoring and evaluating progress towards the SDGs. As of 17 December 2015, a list of 229 indicators was compiled in a proposal for the framework (United Nations Economic and Social Council, 2016).

The proposed SDG indicators make nearly three dozen references to the GDP metric, including a target for more growth in the least developed countries (United Nations Economic and Social Council, 2016). None of the references exploits possible synergies or addresses tensions between sources of GDP growth and the SDGs. Si- mon Kuznets, who is credited with developing the GDP measure, never intended GDP to be used as a gauge of general social welfare. Kuznets noted, "Distinctions must be kept in mind between quantity and quality of growth, between costs and returns, and between the short and long term. Goals for more growth should specify more growth of what and for what" (Kuznets, 1962).

The specification of "more growth of what and for what" is limited in the current formulation of the targets and their indicators. Attempts to propose macroeconomic progress metrics as alternatives to GDP, which incorporate health, wellbeing, and other sustainability considerations were made in the past, e.g., the Index of Sustainable Economic Welfare (Daly \& Cobb, 1989) and the Genuine Progress Indicator (Talberth, 2007). GDP remains the paramount macro-economic metric, to a large extent due to its simplicity and universality (Costanza, Hart, Posner, \& Talberth, 2009). To account for "growth of what and for what" in relation to SDGs, complementary macro-economic progress metrics could be developed reflecting the extent to which economic growth of different countries is aligned with their progress towards the SDGs. Such metrics could be used to monitor whether a country's growth becomes more sustainable and more beneficial for the health of the global population. Criteria of what is more sustainable in this context should be defined on the basis of SDG targets and indicators, taking into account their interactions. Interactions concerning SDG 3 may also engage those who would favour interpreting the term "sustainable economic growth" as "sustained". For example, current contributions of economic growth to population health may secure higher potential for economic growth in the future through the links of good population health with higher future human resources and productivity.

\subsection{Accounting for Long-Term and Non-Monetary Values}

Apart from macro-economic progress indicators and policies, individual participants in the economy and particularly the financial system can be engaged in facilitating progress towards the SDGs through socially responsible investment mechanisms encouraging consideration of long-term and non-monetary values compliant with the SDGs in their financial decisions. Existing mechanisms include positive and negative screening, disinvestment, and shareholder engagement. Often, elements of such mechanisms are already aligned with SDGs such as SDG 3 on health. For example, positive screening often includes health and safety considerations addressing such targets of SDG 3 as exposure to hazardous chemicals and pollutants and prevention of substance abuse (Youssef \& Whyte, 2013). Climate change impacts have also been considered in more traditional financial decision-making tools, for example, in the design of the long-term investment portfolio risk management strate- 
gies (Mercer, 2015) and in the insurance sector (Gurenko, 2006; Xu, 2014).

Further incentives for the focus on long-term and non-monetary value creation in the business sector could also be achieved through managerial innovation; for example, restructuring executive remuneration schemes in a way that increases the proportion of their compensation based on long-term company performance (EY Poland, 2014). Greater focus on the longterm performance of companies, in turn, would allow more time for costumer choice to be reflected in a company's performance metrics. Concurrently, consumers and other stakeholders could be sensitized to the social and environmental impacts of businesses pertinent to the SDGs such as health and its determinants, at their individual and community levels through comprehensive education and communication strategies.

The above-illustrated approaches could be adapted and used in governance for the SDGs. Approaches similar to HiAP could further be used to ensure policy coherence and use of shared policies across sectors (BecerraPosada, 2015). HiAP is particularly relevant for this purpose as it focuses on the determinants of health, which are mostly governed by sectors other than the health sector, requiring complex integrated governance solutions. Establishment of virtual intersectoral boards and taskforces would be required to identify synergies across the SDGs and to devise as well as implement ways of accounting for such effects in daily policy decisions while monitoring progress towards the SDGs.

\subsection{Beyond Reductionism: Climate Change in Wider Policy Contexts}

Development of intersectoral governance mechanisms requires policy framing that permits and encourages intersectoral links. Currently, climate change in policy is mostly formulated as a somewhat isolated environmental process influenced by humanity. Despite its numerous links with many other policies such as those on health and disaster risk reduction, the policy and political processes of climate change have separated it from many other environmental and policy topics.

In the SDGs, climate change is formulated as a separate goal, SDG 13. A footnote to SDG 13 states "Acknowledging that the United Nations Framework Convention on Climate Change is the primary international, intergovernmental forum for negotiating the global response to climate change" (UN Sustainable Development Platform, 2015). Emphasis on a single forum for negotiations on climate change action may ideologically segregate the issue from other intergovernmental fora that could further facilitate addressing climate change impacts.

A contrast can be made with disaster risk reduction policies. As the agreements for the SDGs and UNFCCC (2015) were shaping up, in March 2015 a voluntary international agreement was signed under UNISDR (United Nations Office for Disaster Risk Reduction) auspices, the
Sendai Framework for Disaster Risk Reduction (SFDRR; UNISDR, 2015), also running from 2015-2030. The agreement notes the health and economic benefits of disaster risk reduction, synergising with the discussion here regarding climate change.

For example, the outcome in paragraph 16 of UNISDR $(2015$, p. 9) is "The substantial reduction of disaster risk and losses in lives, livelihoods and health and in the economic, physical, social, cultural and environmental assets of persons, businesses, communities and countries" specifically noting both health and economics. Paragraph 18 of UNISDR (2015, p. 9) includes disaster risk reduction targets to "Reduce direct disaster economic loss in relation to global gross domestic product" (clause c) and "Substantially reduce disaster damage to critical infrastructure and disruption of basic services, among them health and educational facilities" (clause d). As a result, disaster risk reduction measures aim to help minimize negative health and economic impacts of disasters-and often succeed through saving lives (meaning reduced adverse health outcomes) and saving money, as demonstrated by benefit-cost analyses of disaster risk reduction interventions (Shreve \& Kelman, 2014).

Climate change is reasonably integrated into SFDRR across DRR contexts; however, the statement "The climate change issues mentioned in this Framework [SFDRR] remain within the mandate of the United Nations Framework Convention on Climate Change under the competences of the Parties to the Convention" (UNISDR, 2015, p. 11) distances climate change from the DRR mandate instead of fully integrating it into DRR. Hence, the wording of SFDRR separates governance on climate change action and on disaster risk reduction while the wording of the SDGs segregates global governance on climate change from intergovernmental fora other than the UNFCCC.

Climate change policy integration with disaster risk reduction policies would benefit climate change adaptation efforts. Climate change is an important influence, by affecting several hazards including storms, temperature, precipitation, and infectious disease, sometimes exacerbating the hazards and sometimes diminishing them. As opposed to the policy framing in disaster risk reduction, which ensures connections across all hazards, an isolated focus on climate change may constrain instead of facilitate intersectoral synergies supporting climate change action (UNISDR, 2015).

To move beyond the reductionism of climate change and its separation from other processes, especially for connecting health and economic benefits, considering wider policy contexts is necessary. The SDGs, to a large extent, have mainstreamed disaster risk reduction by mentioning the process in numerous SDGs and targets (UN Sustainable Development Platform, 2015). As such, disaster risk reduction is not a standalone process with its own separate SDG but, rather, is integrated into sustainable development. Climate change, as a single hazard influencer among many, was not accorded similar treatment. 


\section{Conclusion}

Comprehensiveness of the SDG framework offers an opportunity to exploit interactions across the goals. Apart from synergistic interactions, tensions between some of the goals are likely, as shown by our analyses of SDGs 8 and 13, alongside their links with SDG 3 on health followed by the comparison with disaster risk reduction. The reductionist approaches prevalent in economics, such as "externalities", GDP, positive discount rates, and short-term profit targets are likely to be some of the key sources of possible tension between SDGs 8 and 13 . These approaches do poorly in considering the complex links among the SDGs, an example being health impacts of climate change and their further implications for economic growth.

In terms of its theoretical value, this paper provides a conceptual baseline for overcoming reductionist approaches. As discussed in section 6.4., health and economic considerations are frequently interpreted and applied in a reductionist manner. The formulation of climate change in policy contexts is often structured in a reductionist manner. However, opportunities for integrating climate change action with policies in other fields could enhance the effectiveness and efficiency of action on climate change. We have provided theoretical suggestions and examples of how to retain the important components of all three topics without becoming ensnared in reductionist thinking.

In terms of its policy value, this paper suggests the intersectoral governance mechanism of HiAP and the development of complementary economic progress metrics aligned with the SDGs. Considering the health impacts of policies-such as those related to economics, climate change, and wider disaster risk reduction-in order to ensure health benefits while avoiding deleterious health consequences would be an important step forward in sustainable development approaches. Here, the importance of HiAP for SDG 8 is demonstrated, yet the lessons apply to policies related to other SDGs and their interactions.

Suggestions made in this paper also have value for practice, particularly when making investment decisions for financial portfolios or development projects. Alternatives to carbon-intensive and growth-focused investments are provided, suggesting how a health focus could lend itself to paybacks and outcomes which might not match economic goals, but which are nonetheless sound economic decisions by supporting healthy people and communities.

The growing recognition of a wide range of socioeconomic factors influencing human health and wellbeing has facilitated development of intersectoral governance approaches, such as HiAP. These approaches could be adapted and incorporated into governance for the SDGs, especially through comparison and analysis of SDGs beyond the three considered here.

\section{Acknowledgements}

We thank Professor Tord Kjellstrom for informative discussions around the topic of this paper.

\section{Conflict of Interests}

The authors declare no conflict of interests.

\section{References}

Ampaabeng, S. K., \& Tan, C. M. (2013). The long-term cognitive consequences of early childhood malnutrition: The case of famine in Ghana. Journal of Health Economics, 32(6), 1013-1027. doi:10.1016/j.jhealeco. 2013.08.001

Anielski, M. (2007). The economics of happiness: Building genuine wealth. Gabriola Island, BC: New Society Publishers.

Becerra-Posada, F. (2015). Health in all polices: A strategy to support the Sustainable Development Goals. The Lancet Global Health, 3(7), e360. doi:10.1016/S2214109X(15)00040-6

Beckerman, W., \& Hepburn, C. (2007). Ethics of the discount rate in the Stern Review on the economics of climate change. World Economics, 8(1), 187-211.

Black, R. E., Victora, C. G., Walker, S. P., Bhutta, Z. A., Christian, P., de Onis, M., ... Uauy, R. (2013). Maternal and child undernutrition and overweight in lowincome and middle-income countries. The Lancet, 382(9890), 427-451.

Brandt, J., Silver, J. D., Frohn, L. M., Christensen, J. H., Andersen, M. S., Geels, C., . . . Skjøth, C. A. (2010). Assessment of health-host externalities of air pollution at the national level using the EVA model system. In International Conference on Energy, Environment and Health-Optimisation of Future Energy Systems (pp. 91-95). Copenhagen. Retrieved from http://www2.dmu.dk/1_om_dmu/2_afdelinger/3_a tmi/ceeh/Collection of Extended Abstracts.pdf\#page $=103 \backslash$ nhttp://vbn.aau.dk/ws/files/75300233/MSJ_ prod21325659713716.RESS-workshop_short_abstra ct_J\%C3\%B8rgensen_J\%C3\%B8rgensen_Lauridsen \%5B1\%5D.pdf

Bronen, R., \& Chapin III, F. S. (2013). Adaptive governance and institutional strategies for climateinduced community relocations in Alaska. Proceedings of the National Academy of Sciences of the United States of America, 110(23), 9320-9325.

Brulle, R. J. (2015). Climate change and society: Sociological perspectives. New York: Oxford University Press.

Canadell, J. G., Le Quéré, C., Raupach, M. R., Field, C. B., Buitenhuis, E. T., Ciais, P., . . . Marland, G. (2007). Contributions to accelerating atmospheric $\mathrm{CO}_{2}$ growth from economic activity, carbon intensity, and efficiency of natural sinks. Proceedings of the $\mathrm{Na}$ tional Academy of Sciences of the United States of America, 104(47), 18866-18870. doi:10.1073/pnas. 
0702737104

Cole, D. H. (2007). The Stern Review and its critics: Implications for the theory and practice of benefit-cost analysis. Natural Resouces Journal, 48(53).

Costanza, R., Hart, M., Posner, S., \& Talberth, J. (2009). Beyond GDP: The need for new measures of progress. Boston University, (4), 1-47.

Daly, H. E., \& Cobb, J. B. (1989). For the common good: Redirecting the economy towards community, the environment, and a sustainable future. Boston: Beacon Press.

DARA, \& Climate Vulnerable Forum. (2012). Climate vulnerability monitor: A guide to the cold calculus of a hot planet (2nd ed.). Madrid: Estudios Graficos Europeos.

Dawson, R. J., Hall, J. W., Bates, P. D., \& Nichloss, R. J. (2005). Quantified analysis of the probability of flooding in the Thames Estuary under imaginable worstcase sea level rise scenarios. International Journal of Water Resources Development, 21(4), 577-591.

DeCanio, S. J., de Lavergne, C., \& Palter, E. D. (2003). Economic models of climate change. New York: Palgrave MacMillan.

Demirguc-Kunt, A., \& Levine, S. (2001). Financial structure and economic growth: Comparison of banks, markets, and development. New York: The MIT Press.

Dercon, S., \& Porter, C. (2014). Live aid revisited: Longterm impacts of the 1984 Ethiopian famine on children. Journal of the European Economic Association, 12(4), 927-948.

Dewey, K. G., \& Begum, K. (2011). Long-term consequences of stunting in early life. Maternal and Child Nutrition, 7(Suppl. 3), 5-18.

Environment Agency London. (2012). Managing flood risk through London and the Thames estuary Thames Estuary 2100. Retrieved from https://www.gov.uk/ government/publications/thames-estuary-2100-te 2100

EY Poland. (2014). Short-termism in business: Causes, mechanisms and consequences. Retrieved from http://www.ey.com/Publication/vwLUAssets/EY_Pol and_Report/\$FILE/Short-termism_raport_EY.pdf

Fitzgerald, V. (2006). Financial development and economic growth: A critical view. Retrieved from http:// www.un.org/en/development/desa/policy/wess/we ss_bg_papers/bp_wess2006_fitzgerald.pdf

Glantz, M. H. (1996). An outsider's view of the world of natural hazards. In R. L. Heathcote, C. Cuttler, \& J. Koetz (Eds.), Conference on Natural Disaster Reduction 1996: Conference Proceedings (pp. 389-396). Barton: Institution of Engineers Australia.

Glantz, M. H., \& Jamieson, D. (2000). Societal response to Hurricane Mitch and intra- versus intergenerational equity issues: Whose norms should apply? Risk Analysis, 20(6), 869-882.

Grossman, G., \& Krueger, A. (1995). Economic growth and the environment. Quarterly Journal of Economics, 110(2), 353-377.

Gurenko, E. N. (2006). Climate change and insurance:
Disaster risk financing in developing countries. Oxon: Earthscan.

Hall, C., \& Klitgaard, K. (2011). Energy and the wealth of nations. New York, NY: Springer.

Handrich, L., Kemfert, C., Mattes, A., Pavel, F., \& Thure, T. (2015). Turning point: Decoupling greenhouse gas emissions from economic growth. Washington, DC: Heinrich-Böll-Stiftung.

Henriques, S. T. (2011). Energy transitions, economic growth and structural change: Portugal in a long-run comparative perspective. Lund: Lund University.

Inglehart, R., Foa, R., Peterson, C., \& Welzel, C. (2008). Development, freedom, and rising happiness: A global perspective (1981-2007). Perspectives on Psychological Science, 3(4), 264-285.

Intergovernmental Panel on Climate Change (IPCC). (2014). Summary for policymakers. In C. B. Field, V. R. Barros, D. J. Dokken, K. J. Mach, M. D. Mastrandrea, T. E. Bilir, ... L. L. White (Eds.), Climate change 2014: Impacts, adaptation, and vulnerability. Part A: Global and sectoral aspects (pp. 1-32). Cambridge: Cambridge University Press.

Jacob, K., Gornitz, V., \& Rosenzweig, C. (2007). Vulnerability of the New York City metropolitan area to coastal hazards, including sea-level rise: Inferences for urban coastal risk management and adaptation policies. In L. McFadden, R. Nicholls, \& E. PenningRowsell (Eds.), Managing coastal vulnerability (pp. 139-156). Oxford: Elsevier.

Kelman, I. (2015). Difficult decisions: Migration from small island developing States under climate change. Earth's Future, 3(4), 133-142.

Kjellstrom, T. (2015). Impact of climate conditions on occupational health and related economic losses: A new feature of global and urban health in the context of climate change. Asia-Pacific Journal of Public Health. doi:10.1177/1010539514568711

Kraussman, F., \& Haberi, H. (2002). The process of industrialization from the perspective of energetic metabolism: Socioeconomic energy flows in Austria. Ecological Economics, 41(2), 177-201.

Kuznets, S. (1962, October 20). How to judge quality. The New Republic, p. 29.

Layard, R. (2003). Happiness: Has social science a clue? In Lionel Robbins Memorial Lectures 2002/3 at the London School of Economics (pp. 1-23). London: London School of Economics.

Layard, R. (2005). Happiness: Lessons from a new science. Penguin Press.

Matthews, H. S., \& Lave, L. B. (2000). Applications of environmental valuation for determining externality costs. Environmental Science and Technology, 34(8), 1390-1395.

Mercer. (2015). Investing in a time of climate change. Retrieved from http://www.mercer.com/services/in vestments/investment-opportunities/responsible-in vestment/investing-in-a-time-of-climate-change-re port-2015.html 
Navrud, S. (2001). Valuing health impacts from air pollution in Europe. Environmental and Resource Economics, 20(4), 305-329.

OECD. (2003). Externalities. Retrieved from https://stats. oecd.org/glossary/detail.asp?ID=77

Parks, B. C., \& Roberts, J. T. (2010). Climate change, social theory and justice. Theory, Culture \& Society, 27(23), 134-166.

Paulson, H. M. (2015). Short-termism and the threat from climate change. Retrieved from http://www. mckinsey.com/insights/strategy/short-termism_and _the_threat_from_climate_change

Peters, G. P., Marland, G., Le Quere, C., Boden, T., Canadell, J. G., \& Raupach, M. R. (2012). Rapid growth in $\mathrm{CO}_{2}$ emissions after the 2008-2009 global financial crisis. Nature Climate Change, 2(1), 2-4. Retrieved from doi:10.1038/nclimate1332

PWC. (2015). Conscious uncoupling? Low carbon economy index 2015. Retrieved from https://www. pwc.com/gx/en/psrc/publications/assets/consciousuncoupling-low-carbon-economy-index-2015.pdf

Rousseau, P., \& Sylla, R. (2001). Financial systems, economic growth, and globalization. Retrieved from http://www.nber.org/papers/w8323

Sahu, S., Sett, M., \& Kjellstrom, T. (2013). Heat exposure, cardiovascular stress and work productivity in rice harvesters in India: Implications for a climate change future. Industrial Health, 51(4), 424-431.

Schandl, H., Hatfield-Dodds, S., Wiedmann, T., Geschke, A., Cai, Y., West, J., . . \& \& Owen, A. (2015) Decoupling global environmental pressure and economic growth: Scenarios for energy use, materials use and carbon emissions. Journal of Cleaner Production, 132, 45-56.

Shreve, C. M., \& Kelman, I. (2014). Does mitigation save? Reviewing cost-benefit analyses of disaster risk reduction. International Journal of Disaster Risk Reduction, 10(A), 213-235.

Island Vulnerability. (1989). Small States conference on sea level rise 14-18 November 1989 Male, the Maldives. Retrieved from http://www.islandvulner ability.org/sIr1989.html

Steinberger, J. K., Krausmann, F., Getzner, M., Schandl, H., \& West, J. (2013). Development and dematerialization: An international study. PloS One, 8(10), e70385.

Storlazzi, C. D., Elias, E. P. L., \& Berkowitz, P. (2015). Many atolls may be uninhabitable within decades due to climate change. Scientific Reports, 5, 14546.

Stott, R. (2012). Contraction and convergence: The best possible solution to the twin problems of climate change and inequity. British Medical Journal, 344, e1765.

Talberth, J. (2007). The genuine progress indicator redefining progress. Retrieved from http://rprogress. org/publications/2007/GPI 2006.pdf

The Economist Intelligence Unit. (2015). The cost of inaction: Reconciling the value at risk from climate change. Retrieved from http://www.economistin sights.com/financial-services/analysis/cost-inaction

UN. (2012). Letter dated 18 June 2012 from the Per- manent Representative of Brazil to the United $\mathrm{Na}$ tions addressed to the Secretary-General of the United Nations Conference on Sustainable Development. Retrieved from http://www.unep.org/rio20/ portals/24180/Docs/a-conf.216-5_english.pdf

UN. (2015). The Millennium Development Goals Report. United Nations. Retrieved from https://visit.un.org/ millenniumgoals/2008highlevel/pdf/MDG_Report_ 2008_Addendum.pdf

UN Sustainable Development Platform. (2015). Sustainable development goals. Retrieved from https:// sustainabledevelopment.un.org/topics

UNFCCC. (2015). Adoption of the Paris Agremeent: Proposal by the President Draft decision-/CP.21. Retrieved from https://unfccc.int/resource/docs/2015/ cop21/eng/l09.pdf

UN Economic and Social Council. (2016). Report of the inter-agency and expert group on sustainable development goal indicators. Retrieved from http://un stats.un.org/unsd/statcom/47th-session/documents/ 2016-2-SDGs-Rev1-E.pdf

Waage, J., Banerji, R., Campbell, O., Chirwa, E., Collender, G., Dieltiens, V., . . . Unterhalter, E. (2010). The millennium development goals: A cross-sectoral analysis and principles for goal setting after 2015. doi:10.1016/S0140-6736(10)61196-8

Waage, J., Yap, C., Bell, S., Levy, C., Mace, G., Pegram, T., ... Poole, N. (2015). Governing the UN sustainable development goals: Interactions, infrastructures, and institutions. The Lancet Global Health, 3(5), e251-e252. doi:10.1016/S2214-109X(15)70112-9

Ward, R., \& Smith, K. (1998). Floods: Physical processes and human impacts. Chichester: John Wiley \& Sons.

Watts, N., Adger, W. N., Agnolucci, P., Blackstock, J., Byass, P., Cai, W., . . . Costello., A. (2015). Health and climate change: Policy responses to protect public health. The Lancet, 386(10006), 1861-1914.

Weitzman, M. L. (2007). A review of the stern review on the economics of climate change. Journal of Economic Literature, 45(3), 703-724.

Winkler, M. S., Krieger, G. R., Divall, M. J., Cissé, G., Wielga, M., Singer, B. H., . . . Utzinger, J. (2013). Untapped potential of health impact assessment. Bulletin of the World Health Organization, 91(4), 298305. doi:10.2471/BLT.12.112318

World Health Organization. (2014). Health in all policies: Helsinki statement, 21. doi:10.1093/heapro/dau035

Worldwatch Institute. (2015). State of the world report. Retrieved from http://www.worldwatch.org/stateof-the-world-2015

$X u, X$. (2014). Climate change as a challenge to China's insurance industrynull. International Journal of Climate Change Strategies and Management, 6(4), 363-375.

Youssef, S., \& Whyte, D. (2013). Ethical investment: What it is and how it works (or doesn't). Retrieved from https://corporatewatch.org/magazine/54/summer2013/ethical-investment-what-it-and-how-it-worksor-doesnt 


\section{About the Authors}
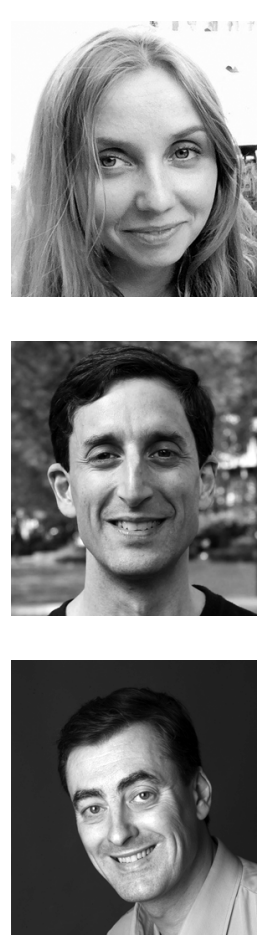

Kristine Belesova is a PhD candidate in Global Public Health and Environmental Epidemiology at the London School of Hygiene and Tropical Medicine (LSHTM). Her research examines possible impacts of climate change and extreme weather on food systems and human health. Kristine is also interested in the design and evaluation of policy and governance strategies for sustainable development. She leads the course "Environmental Change and Global Health Policy" at LSHTM and lectures at University College London and Heidelberg University.

Ilan Kelman is a Reader in Risk, Resilience and Global Health at University College London, UK, and a researcher at the University of Agder, Norway. His overall research interest is linking disasters and health, including the integration of climate change into disaster research and health research. That covers three main areas: (i) disaster diplomacy and health diplomacy; (ii) island sustainability; and (iii) risk education for health and disasters.

Roger Boyd is a retired financial industry executive, where he worked for 25 years. He received an MBA in Finance from Stern School of Business, New York University in the United States and an MA in Integrated Studies from Athabasca University in Canada. Over the past decade he has taken a deepening interest in the way in which modern societies, especially their financial systems, will deal with global threats such as energy constraints and climate change. 